Главный редактор

Б. П. ТУМАНЯН - д.Т.Н., проф.

Научно-редакционный совет А. Ф. ВИЛЬДАНОВ - д.т.н., проф. А. И. ВЛАДИМИРОВ - к.Т.Н., проф А. И. ГРИЦЕНКО - д.Т.Н., проф. А. Н. ДМИТРИЕВСКИЙ - д.г.-м.н., проф.

О. Н. КУЛИШ - д.т.н., проф. А. Л. ЛАПИДУС - д.х.н., проф. ЛИГОЮЙ - проф. (Китай) Н. А. МАХУТОВ - д.Т.н., проф. И. И. МОИСЕЕВ - д.Х.н., проф.

Б. П. ТОНКОНОГОВ - д.х.н., проф. К. TPABEP - проф. (Франция)

В. А. ХАВКИН - д.Т.н., проф. М. ЦЕХАНОВСКА - д.Т.Н., проф. (Польша)

Head Editor

B. P. TUMANYAN - Dr. Eng. Sci., prof.

Editorial Board

A. F. VIL'DANOV - Dr. Eng. Sci., prof. A. I. VLADIMIROV - Cand. Eng. Sci., prof. A. I. GRITSENKO - Dr. Eng. Sci., prof.

A. N. DMITRIEVSKY -

Dr. Geo.-Min. Sci., prof.

O. N. KULISH - Dr. Eng. Sci., prof. A. L. LAPIDUS - Dr. Chem. Sci., prof.

LI GO IUY - prof. (China) N. A. MAKHUTOV - Dr. Eng. Sci., prof. I. I. MOISEEV - Dr. Chem. Sci., prof.

B.P. TONKONOGOV -

Dr. Chem. Sci., prof.

Ch. TRAVERS - prof. (France) V. A. KHAVKIN - Dr. Eng. Sci., prof. M. TSEKHANOVSKA -

Dr. Eng. Sci., prof. (Poland)

Журнал издается в Российском государственном университете нефти и газа им. И. М. Губкина

\section{тЕХнОЛОГИИ НЕФТИ ИТАЗА научно-технологический журнал \\ DOI: 10.32935/1815-2600-2020-126-1

\section{СОДЕ РЖАНИЕ}

\section{ИССЛЕДОВАНИЯ}

Е. В. Францина, Н. И. Кривцова, Т. И. Бабий

ТЕРМОДИНАМИЧЕСКИЙ АНАЛИЗ РЕАКЦИЙ ПРЕВРАЩЕНИЯ

АЗОТСОДЕРЖАЩИХ СОЕДИНЕНИЙ В ПРОЦЕССЕ

ГИДРООЧИСТКИ ДИЗЕЛЬНЫХ ФРАКЦИЙ НА ОСНОВЕ

КВАНТОВО-ХИМИЧЕСКИХ РАСЧЕТОВ.

А. А. Гасанов, Н. Х. Гамзаева

МОДЕЛИРОВАНИЕ ОСАЖДЕНИЯ ТВЕРДОЙ ЧАСТИЦЫ

ПРИ ОЧИСТКЕ НЕФТИ В ГРАВИТАЦИОННОМ СЕПАРАТОРЕ. 8

Л. А. Магадова, Д. Н. Малкин,

С. А. Бородин, Е. С. Кратнова

ИССЛЕДОВАНИЕ НАБУХАНИЯ ГЛИНОПОРОШКОВ

РАЗЛИЧНОГО ПРОИСХОЖДЕНИЯ.

Л. А. Магадова, Ву Вьет Тхань, М. Д. Пахомов,

Нгуен Куок Зунг, В. Б. Губанов

РАЗРАБОТКА КИСЛОТНОЙ КОМПОЗИЦИИ

С УЧЕТОМ МИНЕРАЛОГИЧЕСКОГО СОСТАВА

И УСЛОВИЙ ИНТЕРВАЛА ОТЛОЖЕНИЙ НИЖНЕГО МИОЦЕНА

МЕСТОРОЖДЕНИЯ «БЕЛЫЙ ТИГР»

ГЕОЛОГИЯ И ГЕОФИЗИКА

О. В. Тюкавкина

ПРИМЕНЕНИЕ СТАТИСТИЧЕСКИХ МЕТОДОВ

ДЛЯ ОПТИМИЗАЦИИ И АВТОМАТИЗАЦИИ ПОДБОРА

КОМПЛЕКСА ТЕХНОЛОГИЙ ЭКСПЛУАТАЦИОННОЙ РАЗВЕДКИ

НА МЕСТОРОЖДЕНИЯХ, ВОВЛЕЧЕННЫХ

В ПРОМЫШЛЕННОЕ ОСВОЕНИЕ 


\section{РАЗРАБОТКА И ЭКСПЛУАТАЦИЯ} МЕСТОРОЖДЕНИЙ НЕФТИ И ГАЗА

Н. Р. Яркеева, Д. В. Имангулов

АНАЛИЗ ЭФФЕКТИВНОСТИ ПРОВЕДЕНИЯ

ЗАРЕЗКИ БОКОВЫХ СТВОЛОВ

НА ВАРЬЕГАНСКОМ МЕСТОРОЖДЕНИИ

\section{ОБОРУДОВАНИЕ}

А. В. Митрофанов, А. Б. Меньшин, О. Н. Лисовский

МЕТОДИКА ДИАГНОСТИРОВАНИЯ И ИССЛЕДОВАНИЯ

НАПРЯЖЕННО-ДЕФОРМИРОВАННОГО СОСТОЯНИИ

ФИЛЬТР-СЕПАРАТОРОВ ПРИРОДНОГО ГАЗА

С ЗАПРЕДЕЛЬНЫМИ ОТКЛОНЕНИЯМИ

В БЫСТРОСЪЕМНЫХ СКОБОВЫХ ЗАТВОРАХ

Л. М. Ахметзянов

ОПТИМИЗАЦИЯ ЗАТРАТ ПРИ ЭКСПЛУАТАЦИИ

РЕДУКТОРОВ СТАНКОВ-КАЧАЛОК

\section{ТРАНСПОРТ НЕФТИ И ГАЗА}

А. О. Туркин, С. В. Суховерхов, В. Б. Логвинова, Н. А. Прокуда

ПРИМЕНЕНИЕ РАСТВОРИТЕЛЯ ДЛЯ УДАЛЕНИЯ

АСФАЛЬТОСМОЛОПАРАФИНОВЫХ ОТЛОЖЕНИЙ

ИЗ МОРСКОГО ТРУБОПРОВОДА НЕФТИ.

А. С. Мокроусов

ВОЕННО-ЭКОНОМИЧЕСКАЯ ОПТИМИЗАЦИЯ

ВМЕСТИМОСТИ ПОЛЕВЫХ СКЛАДОВ ГОРЮЧЕГО

С УЧЕТОМ МЕСТНОЙ ИНФРАСТРУКТУРЫ .47

\section{ЭКОНОМИКА И ФИНАНСЫ}

К. В. Дозмаров Т. С. Басова

ПРИМЕР ИЗ АНТИМОНОПОЛЬНОЙ ПРАКТИКИ

В НЕФТЕГАЗОВОЙ СФЕРЕ:

ПОСЛЕДСТВИЯ ВЫДАЧИ ПРЕДПИСАНИЙ

АНТИМОНОПОЛЬНОГО ОРГАНА В РАМКАХ КОНТРОЛЯ

ЗА ЭКОНОМИЧЕСКОЙ КОНЦЕНТРАЦИЕЙ

\section{ИСТОРИЯ}

Т. Г. Гюльмисарян, И. П. Левенберг

ИСТОРИЯ ТЕРМОГАЗОЙЛЯ

\section{PERSONALIA}

К 9О-ЛЕТИЮ СО ДНЯ РОЖДЕНИЯ

ПРОФЕССОРА ЗАГИДУЛЛЫ ИСХАКОВИЧА СЮНЯЕВА
Директор по информации Н. П. ШАПОВА

Редактор

В. С. ДМИТРИЕВА

Верстка

B. B. $3 E M C K O B$

Подготовка материалов Т. С. ГРОМОВА

Издатель - Международный центр науки и технологий «ТУМА ГРУПП»

Адрес редакции:

111116 , Москва,

ул. Авиамоторная, 6

Тел./факс: (499) 135-88-75

e-mail: tng98@list.ru

Интернет: http://www.nitu.ru

При перепечатке любых материалов ссылка на журнал

«Технологии нефти и газа» обязательна

\section{Nol ${ }^{(126)} 2020$}

Журнал зарегистрирован

в Министерстве РФ по делам печати, телерадиовещания и средствам

массовой коммуникации

Свидетельство о регистрации ПИ № 77-16415 от 22.09.2003 г.

ISSN 1815-2600

Включен в перечень изданий Высшей аттестационной комиссии Министерства образования и науки РФ

Тираж 1200 экз.

Редакция не несет ответственности за достоверность информации в материалах, в том числе рекламных, предоставленных авторами для публикации

Материалы авторов не возвращаются

Отпечатано в ООО ИПФ «СТРИНГ» 424006, Республика Марий Эл,

г. Йошкар-Ола, ул. Строителей, 95 
Термодинамический анализ реакций превращения азотсодержащих соединений в процессе гидроочистки дизельных фракций на основе квантово-химических расчетов

Е. В. Францина, Н. И. Кривцова, Т. И. Бабий

Национальный исследовательский Томский политехнический университет evf@tpu.ru

На основе квантово-химических расчетов методом теории функиионала плотности DFT (модель теоретического приближения B3LYP, базис 3-21G) проведена оченка термодинамических параметров реакиий азотсодержащих соединений в процессе гидроочистки дизельных фракций при температуре $400^{\circ} \mathrm{C} u$ давлении 2 МПа. На основании термодинамического анализа выделены следующие группь азотсодержащих соединений: моноароматические углеводороды с положением атома азота в кольце, диароматические углеводороды с положением атома азота в кольце, монозамещенные диароматические углеводороды с положением атома азота в кольче, триароматические углеводороды с положением атома азота в кольие, алкилзамещенные нитриль, ароматические нитрилы, ароматические амины.

На основе результатов термодинамического анализа определена вероятность протекания реакиий, предложена реакционная схема превращений углеводородов, которая может быть использована при разработке математической модели процесса гидроочистки дизельных фракций с учетом превращений азотсодержащих соединений.

Ключевые слова: гидроочистка, дизельная фракция, азотсодержащие соединения, квантово-химические расчеты.

DOI: $10.32935 / 1815-2600-2020-126-1-3-7$

\section{E. V. Frantsina, N. I. Krivtcova, T. I. Babyi}

National Research Tomsk Polytechnic University

\section{Thermodynamic Analysis of the Nitrogen-Containing Compounds Conversion in the Process} of Diesel Fractions Hydrotreatment Based on Quantum Chemical Calculations

Based on quantum chemical calculations using the DFT density functional theory method (B3LYP theoretical approximation model, basis 3-21G), thermodynamic parameters of the nitrogen-containing compounds reactions in the diesel fractions hydrotreating process at a temperature of $400^{\circ} \mathrm{C}$ and a pressure of $2 \mathrm{MPa}$ were evaluated. The following groups of nitrogen-containing compounds: monoaromatic hydrocarbons position nitrogen atom in the ring, diaromatic hydrocarbons position nitrogen atom in the ring, monosubstituted diaromatic hydrocarbons with the position of the nitrogen atom in the ring, triaromatic hydrocarbons with the position of the nitrogen atom in the ring (acridine, carbazole), alkyl-substituted nitriles, aromatic nitriles, aromatic amines were identified. The probability of reactions was determined, a reaction scheme for the conversion of hydrocarbons was proposed, which can be used to develop a mathematical model of the diesel fractions hydrotreatment process taking into account the conversion of nitrogen-containing compounds.

Key words: hydrotreating, diesel fractions, nitrogen-containing compounds, thermodynamics, quantum-chemical calculations, modeling. 
Моделирование осаждения твердой частицы при очистке нефти в гравитационном сепараторе

А. А. Гасанов, Н. Х. Гамзаева

Азербайджанский государственный университет нефти и промышленности

alakbar48-48@mail.ru

В работе рассмотрен нестаџионарный проиесс осаждения твердой шарообразной частицьь в покоящейся жидкости в гравитаџионном сепараторе. Для описания данного прочесса предлагается математическая модель, учитывающая силь вязкого трения, определяемой на основе полуэмпирической теории турбулентности Прандтля, наследственной силь Бассе, а также силь присоединенной массы. Для реализации предложенной модели используется разностный метод. С помощью численного эксперимента исследованы влияния различных сил на скорость осаждения частиць.

Ключевые слова: гравитационный сепаратор, осаждение, математическая модель, полуэмпирической теории турбулентности Прандтля, сила Бассе.

DOI: $10.32935 / 1815-2600-2020-126-1-8-10$

\author{
A. A. Gasanov, N. Kh. Gamzaeva
}

Azerbaijan State Oil and Industry University

\title{
Modeling of Deposition of Solid Particles at Cleaning of Oil in Gravitational Separator
}

The non-stationary process of sedimentation of a solid spherical particle in a fluid at rest in a gravitational separator is considered. To describe this process, we propose a mathematical model that takes into account viscous friction forces, which is determined on the basis of the Prandtl semi-empirical theory of turbulence, Basse hereditary force, as well as the added mass force. To implement the proposed model, a difference method is used. Using a numerical experiment, the effects of various forces on the particle deposition rate are investigated.

Key words: gravity separator, deposition, mathematical model, Prandtl semi-empirical theory of turbulence, Basse force.

\section{Исследование набухания глинопорошков различного происхождения}

Л. А. Магадова, Д. Н. Малкин, С. А. Бородин, Е. С. Кратнова

РГУ нефти и газа (НИУ) имени И. М. Губкина

lubmag@gmail.com

В статье рассматривается выбор объектов лабораторных исследований для сравнительного анализа эффективности действия стабилизаторов глин. Из-за отсутствия стандартизированной методики проверки стабилизаторов глин в лабораториях используется образщы глин разного происхождения, что, зачастую, приводит к расхождению получаемых результатов. В статье приведень результаты исследований образиов глинопорошков и влияние водных сред на их набухание.

Ключевые слова: набухание, глинопорошки, глина, бентонит, монтмориллонит, рентгеноструктурный анализ, рентгенофазовый анализ.

DOI: 10.32935/1815-2600-2020-126-1-11-16 
L. A. Magadova, D. N. Malkin, S. A. Borodin, E. S. Kratnova

Gubkin Russian State University of Oil and Gas (National Research University)

\section{Study of Swelling of Variously Originated Clay Powders}

This article discusses the selection of objects for laboratory research on comparative analysis of the effectiveness of clay stabilizers. There are no federal standards for testing clay stabilizers in Russia. Clay samples of different origin are used in laboratories, which often leads to a lack of convergence of the results. Using different methods does not allow to compare the results obtained in the laboratory. The article provides analysis of ground clay samples of different origin. The effect of aqueous media on it swelling is shown.

Key words: swelling, clay powders, clay, bentonite, montmorillonite, $X$-ray diffraction analysis, $X$-ray phase analysis.

\section{Разработка кислотной композиции с учетом минералогического состава}

и условий интервала отложений нижнего миоена месторождения «Белый тигр»

Л. А. Магадова, Ву Вьет Тхань, М. Д. Пахомов, Нгуен Куок Зунг, В. Б. Губанов

РГУ нефти и газа (НИУ) имени И. М. Губкина

lubmag@gmail.com

При анализе данных о характеристике пород в осадочном чехле месторождения «Белый Тигр» выявлены продуктивные пласты и горизонты в нижнемиоченовом стратиграфическим комплексе.

Литолого-петрографическая и петрофизическая характеристики пород-коллекторов по керну показывают, что породы-коллекторы нижнего миочена представлены песчаниками, алевролитами и переслаиванием алевролитов, песчаников и гравелито-песчаников. Данный коллектор представляет собой большую проблему при подборе кислотной композиции из-за сложного минералогического состава и высокой пластовой температуры $\left(113-118^{\circ} \mathrm{C}\right)$. Представлены результаты исследований по разработке эффективной кислотной композици с учетом геолого-технических характеристик и минералогического состава данного объекта.

Ключевые слова: минералогический состав, нижний миоцен, глинистость, алевролиты, кислотная композиция, соляная кислота, борфтористоводородная кислота.

DOI: 10.32935/1815-2600-2020-126-1-17-23

L. A. Magadova, Vu Viet Thanh, M. D. Pahomov, Nguyen Quoc Dung, V. B. Gubanov

Gubkin Russian State University of Oil and Gas

\section{Development of Acid Combination Based on the Mineralogical Composition and Conditions of the Lower Miocene Deposits Interval of the White Tiger Oilfield}

After analyzing the sedimentary rock characteristics in the White Tiger oilfield, productive layers and horizons in the Lower Miocene stratigraphic are separated. The lithological, petrographic, and petrophysical characteristics of core samples show that Lower Miocene reservoir rocks are included sandstones, siltstones, and interbedding of siltstones, sandstones, and gravel-sandstones. This type of collector leads to a huge problem in the selection of acid composition due to the complex mineralogical composition and high reservoir temperature $\left(113-118^{\circ} \mathrm{C}\right)$. This article presents the results of studies on the effect of acid in production, which taking to account the geological- technical methods and mineralogical composition of the object. 
Key words: mineralogical composition, clay content, lower miocene, siltstones, acid composition, hydrochloric acid, hydrogen tetrafluoroborate.

\section{Применение статистических методов для оптимизации и автоматизации подбора комплекса технологий} эксплуатационной разведки на месторождениях, вовлеченных в промышленное освоение

О. В. Тюкавкина

Российский государственный геологоразведочный университет им. Серго Орджоникидзе tov.sing@mail.ru

В работе рассмотрены вопросы применения статистических методов для группирования данных, характеризующих литолого-фачиальные условия формирования нефтегазоносных резервуаров, рассмотрены варианты комплексного исследования геофизических и промысловых данных с иелью проведения мероприятий по доразведке и бурению эксплуатационных скважин в пределах юрских горизонтов месторождений центральной части Западно-Сибирской плитыл. Представлены материаль интерпретации литолого-петрографических и фильтраџионно-емкостных свойств коллекторов, группирования объектов с применением кластерного, дискриминантного и факторного анализов, выделения критериев, необходимых для моделирования объектов с тудноизвлекаемыми запасами и принятия решений о способах их разработки.

Ключевые слова: кластерный анализ, факторный анализ, трудноизвлекаемые запасы, геологоразведочные работы.

DOI: 10.32935/1815-2600-2020-126-1-24-29

O. V. Tyukavkina

Sergo Ordzhonikidze Russian State University for Geological Prospecting

Applying Statistical Methods for Optimization and Automation of the Selection of a Complex of Geological Prospecting Work at the Fields, Involved in Industrial Development

This paper address matters related to use of statistical methods for grouping data characterizing the lithofacial conditions of formation of oil and gas reservoirs, considers options for a comprehensive study of geophysical and field data in order to carry out work on additional exploration and drilling of production wells within the Jurassic horizons of fields in the central part of the West Siberian Plate. The materials of interpretation of lithologic-petrographic and reservoir properties of reservoirs, grouping objects using cluster, discriminant and factor analysis, definition the criteria necessary for modeling objects with hard-to-recover reserves and making decisions about how to develop them are presented.

Key words: cluster analysis, factor analysis, hard-to-recover reserves, geological exploration.

\section{Анализ эффективности проведения зарезки боковых стволов на Варьеганском месторождении}

Н. Р. Яркеева, Д. В. Имангулов

Уфимский государственный нефтяной технический университет

dinis.imangulov@gmail.com 
В статье рассматривается один из перспективных методов увеличения нефтеотдачи - зарезка боковьх стволов (ЗБС). Исследовано состояние разработки пласта, на котором применяется данный метод, и обоснован выбор скважин-кандидатов на его проведение. На примере Варьеганского месторождения определена эффективность проведения ЗБС в зависимости от прироста дебита скважин. Используя полученную зависимость, можно оценить темпы увеличения накопленной добычи нефти.

Ключевые слова: геолого-технические мероприятия, зарезка боковых стволов, остаточные извлекаемые запасы, высокая обводненность, накопленная добыча, прирост дебита.

DOI: 10.32935/1815-2600-2020-126-1-30-33

N. R. Yarkeeva, D. V. Imangulov, Ufa State Petroleum Technological University

\section{Analysis of the Efficiency of Sidetracking in the Variogan Field}

The article discusses one of the most promising oil recovery methods - sidetracking (sidetracking), explores the development status of formation that use this method, and justifies the selection of candidate wells for its implementation. Based on the example of the Variogan field, the effectiveness of the sidetracking operations was determined depending on the increase in well production. Using the obtained dependence, we can estimate the rate of increase in cumulative oil production.

Key words: geological and technical activities, sidetracking, residual recoverable reserves, high water cut, cumulative production, increase in yield.

\section{Методика диагностирования и исследования напряженно-деформированного состояния фильтр-сепараторов природного газа с запредельными отклонениями}

\section{в быстросъемных скобовых затворах}

А. В. Митрофанов, А. Б. Меньшин, О. Н. Лисовский

АО «Системы и технологии обеспечения безопасности «ТЕХДИАГНОСТИКА» contact@tdiag.ru

Представлены основные положения новой методики диагностирования и оценки напряженнодеформированного состояния фильтр-сепараторов природного газа с запредельными по критериям действующей методики отклонениями в размерах и положении конструктивньх элементов. Методика содержит указания по построению геометрической модели узла затяжки быстросъемного скобового затвора, включающей большинство отклонений группы фильтр-сепараторов. Обосновывается обобщенная математическая модель для расчета и анализа напряженно-деформированного состояния узла затяжки методом конечных элементов. Предлагается конструкция уменьщенной обобщенной экспериментальной модели для реализации резистивной тензометрии. Приводится алгоритм оченки работоспособности фильтр-сепараторов объединяющий результаты расчетного и экспериментального исследований.

Ключевые слова: методика, диагностирование, фильтр-сепаратор, быстросьемный затвор, напряженно-деформированное состояние, прочность, работоспособностье.

DOI: 10.32935/1815-2600-2020-126-1-34-39 
A. V. Mitrofanov, A. B. Menshin, O. N. Lisovskii

JSC «Sistemy i tekhnologii obespecheniya bezopasnosti. TEKXDIAGNOSTIKA»

Methods Diagnostic and Research of Stressed-Strained State of Natural Gas Filter-Separators with Extremely Deflections in Quick-Opening Closures

The main provisions of the new methods for diagnosing and assessing the stress-strain state of natural gas filter-separators are presented with deviations in the size and position of structural elements that are beyond the criteria of the current methods. The current methods contain instructions for constructing a geometric model of the quick-opening closures, which includes most of the deviations of the filter-separator group. It substantiates a generalized mathematical model for calculating and analyzing the stress-strain state of a tightening node by the finite element method. Offers the construction of a reduced generalized experimental model for the implementation of resistive strain measurement. Provides an algorithm for evaluating the performance of filter-separators combining the results of computational and experimental studies.

Key words: methods, diagnostics, filter-separator, quick-opening closures, stress-strain state, strength, working capacity.

\section{Оптимизация затрат при эксплуатации редукторов станков-качалок}

Л. М. Ахметзянов

НГДУ «Альметьевнефть» ПАО «Татнефть»

ahmetzyanovlm@tatneft.ru

В статье рассмотрены технические решения, направленные на оптимизацию производственных процессов в области эксплуатации оборудования добывающего фонда скважин. В процессе механизированного способа добычи нефти штанговыми скважинными насосными установками существует ряд технических проблем оказывающие серьезное влияние на эффективность эксплуатации добывающего фонда скважин и в целом на объем добычи нефти. Масштабной проблемой при эксплуатации станков-качалок является пропуски масла на редукторах привода.

Ключевые слова: станок-качалка, редуктор, штанговые скважинные установки.

DOI: 10.32935/1815-2600-2020-126-1-40-42

\section{M. Akhmetzyanov}

Oil and Gas Production Department «Almetyevneft» PJSC «Tatneft», Almetyevsk

\section{Cost Optimization in the Operation of Gearbox of Rocking Machine}

In this article, technical solutions aimed at optimizing production processes in the field of operation of equipment of the production well stock are considered. In the process of a mechanized method of oil production by sucker-rod pumping units, there are a number of technical problems that have a serious impact on the efficiency of operation of the production stock of wells and, in general, on the volume of oil production. A large-scale problem in the operation of pumping units is oil leakage on drive gearboxes.

Key words: rocking machine, gearbox, sucker-rod pumping units. 
Применение растворителя для удаления асфальтосмолопарафиновых отложений

из морского трубопровода нефти

А. О. Туркин ${ }^{1}$, С. В. Суховерхов ${ }^{2}$, В. Б. Логвинова ${ }^{2}$, Н. А. Прокуда ${ }^{2}$

${ }^{1}$ Филиал компании «Сахалин Энерджи Инвестмент Компани Лтд.» в г. Южно-Сахалинск,

${ }^{2}$ Институт химии Дальневосточного отделения РАН, г. Владивосток

Andrey.Turkin@sakhalinenergy.ru

Исследован состав асфальтосмолопарафиновых отложений (АСПО) из морского трубопровода нефтедобывающей платформы «ПА-Б» (Пильтун-Астохское месторождение, о. Сахалин). Установлено, что нефть содержит 2,1\% парафинов, состоящих, в основном, из нормальных углеводородов с числом атомов углерода от 28 до 46. Выбран растворитель АСПО, применение которого позволяет поддерживать проектную пропускную способность трубопровода.

Ключевые слова: асфальтосмолопарафиновые отложения, парафины, растворители АСПО.

DOI: $10.32935 / 1815-2600-2020-126-1-43-46$

A. O. Turkin ${ }^{1}$, S. V. Sukhovehov², V. B. Logvinova ${ }^{2}$, N. A. Prokuda ${ }^{2}$

${ }^{1}$ Sakhalin Energy Investment Company, Ltd., ${ }^{2}$ Institute of Chemistry, Far Eastern Branch, Russian Academy of Science Wax Dissolver Application for Pab Off-Shore Pipeline Paraffin Deposits

PA-B off-shore pipeline wax deposits have been analyzed and researched (Piltun-Astokh oil field, Sakhalin island). It is found out that crude oil includes $2.1 \%$ paraffins, basically consisting of normal hydrocarbons with carbon number of 28 to 46. Wax dissolver has been selected, which application allows keeping design pipeline capacity. Key words: crude oil, wax deposits, paraffins, wax dissolvers.

\section{Военно-экономическая оптимизация вместимости полевых складов горючего с учетом местной инфраструктуры}
А. С. Мокроусов
Вольский военный институт материального обеспечения mokrousov85@rambler.ru

В данной статье приведена методика технико-экономической оптимизации параметров полевой системьл хранения горючего, раскрыты основные требования к рассредоточению запасов горючего на полевых складах, их делению на текущие и страховые, обеспечивающие живучесть и производительность по выдаче горючего войскам с учетом технологического складского оборудования.

Ключевые слова: текущий запас, страховой запас, вместимость полевого склада, параметры склада, приведенные стоимостные затраты на хранение горючего.

DOI: 10.32935/1815-2600-2020-126-1-47-52

\section{A. S. Mokrousov}

Volsky military Institute of material support

Military-Economic Optimization of the Capacity of Field Warehouses Fuel Taking into Account Local Infrastructure 
This article presents a technique of technical and economic optimization of parameters of the field fuel storage system, reveals the basic requirements for the dispersion of fuel reserves in the field warehouses, their division into current and insurance, ensuring the survivability and performance of the issuance of fuel to the troops, taking into account the technological warehouse equipment.

Key words: current stock, insurance stock, capacity of field warehouse, warehouse parameters, given the cost of fuel storage costs.

\section{Пример из антимонопольной практики в нефтегазовой сфере:}

\section{последствия выдачи предписаний антимонопольного органа в рамках контроля} за экономической концентрацией

К. В. Дозмаров (адвокат в сфере антимонопольного регулирования),

Т. С. Басова (эксперт-экономист в сфере антимонопольного регулирования)

k.dozmarov@kulik.law, t.basova@kulik.law

В настоящее время правовое поле в сфере экономической концентрации сформировано множеством нормативных правовых актов, ведомственных приказов ФАС России и судебной практики. Безусловно, эти меры направлены на содействие развитию конкуренции и на пресечение нарушений антимонопольного законодательства, но всегда ли предписывающие и превентивные меры со стороны государственной власти являются универсальными для хозяйственной деятельности экономических субъектов? В ответе на этот вопрос помогут разобраться аналитические методы экономической теории, научные труды нобелевских лауреатов мировой экономики, а также собственные наработанные подходы авторов настоящей статьи в антимонопольной практике. Настоящее исследование проводилось для того, чтобы сформировать у читателя «наглядную интерактивную картинку» осуществления контроля за экономической концентрацией, затрагиваемой проблемой непрогнозируемых рыночных сигналов и административно-командных методов государственного регулирования.

Ключевые слова: предписания антимонопольного органа, хозяйственная деятельность, антимонопольная практика, предпочтения потребителей.

DOI: 10.32935/1815-2600-2020-126-1-53-58

K. V. Dozmarov (advocate), T. S. Basova (expert economist)

Orders of Antitrust Authority: an Instrument of Control over Economic Concentration or Negative Element of State Intervention

Currently, the legal field in the field of economic concentration is formed by a variety of regulatory legal acts, departmental orders of the FAS Russia and judicial practice. Of course, these measures are aimed at promoting competition and suppressing violations of antitrust laws, but are always prescriptive and preventive measures by the state authorities universal for the economic activities of economic entities? The answer to this question will help to understand the analytical methods of economic theory, the scientific works of Nobel laureates of the world economy, as well as their own developed approaches of the authors of this article in antitrust practice. 
The present study was carried out in order to form a "visual interactive picture" for the reader to monitor the economic concentration affected by the problem of "unpredictable" market signals

and administrative-command methods of state regulation.

Key words: requirements of the antimonopoly authority, economic activity, antitrust practice, consumer preferences. 